\title{
Total environmental monitoring of a paper and pulp industry in Pakistan
}

\author{
Sana Akhtar*, Iqra Tariq, Almas Hamid, Sunaina Ashfaq \\ Kinnaird College for Women, Lahore, Pakistan
}

Email address:

sanakhtar23@gmail.com (S. Akhtar)

To cite this article:

Sana Akhtar, Iqra Tariq, Almas Hamid, Sunaina Ashfaq. Total Environmental Monitoring of a Paper and Pulp Industry in Pakistan. International Journal of Environmental Monitoring and Analysis. Vol. 1, No. 6, 2013, pp. 307-314. doi: 10.11648/j.ijema.20130106.16

\begin{abstract}
The Paper and Paperboard mill selected for environmental monitoring is a large integrated mill, which uses wheat straw, bagasse and waste paper as a raw material for paper production. The plant produces white and brown paper as well as corrugated cartons. A few upset and spills were found at the mill due to old production procedures, however new interventions were made at a few places to fill in the gaps. Material and water balance were drawn for the industry, which showed that the wastewater produced by the mill was $205.6 \mathrm{~m}^{3} /$ ton of product. The Suspended Solids (SS) and BOD of the wastewater discharged in the Hudiara drain were found to be $431.8 \mathrm{~kg} / \mathrm{ton}$ of product and $726 \mathrm{mg} / \mathrm{l}$, respectively. Similarly sulphide content of the wastewater was also exceeding the relevant environmental standards. Among the stack and air emissions studied, all of the parameters were within the prescribed limits of National Environmental Quality Standards (NEQS). The National standards for noise and illumination were also being violated in some areas of the industry, thus depicting poor ergonomic conditions. The cleaner production opportunities were studied for the mill, which concluded that good housekeeping is required and measures for water conservation should be taken in action, which include, repairing the leakages, using pressure nozzles and keeping the taps closed when not in use.
\end{abstract}

Keywords: Paper and Board Industry, Material Balance, BOD, Noise and Illumination, NEQS, House Keeping

\section{Introduction}

Industrialized economies play a major role in environmental degradation. This is due to the fact that they frequently emit air pollutants, generate solid waste and discharge wastewater, which may deplete, contaminate and deteriorate natural resources. Major industrial contributors to water pollution are the pulp and paper, chemicals, petrochemical refineries, metalworking, food processing and textile industries. Moreover, power generation for various industrial purposes and brick kilns are also major sources of air pollution [1].

Additionally, in most developed countries, small-scale mills are more popular in terms of environmental degradation than larger ones. Small-scale mills usually become a cause for environmental pollution due to outdated technology, poor operational and maintenance practice and other factors. Conversely, agricultural residues as relevant are primarily suitable for smaller scaled mills. However, using agricultural residues can help by reducing the load on use of forest wood. Despite this, it certainly has its adverse environmental impacts in term of pollutant discharge [2-4].
Paper and paper products have shown continuously increasing demand with the passage of time. Consumption of paper and paper board equaled 1.2 million tons in 198081 and increased to 2.6 million tons in 1994-95 [5]. Paper and pulp industries make use of larger quantities of water. The alarming water pollutants in paper production or pulp are the solids that stay suspended like fibre, colour, toxicity and biological oxygen demand. Generally in Paper and Pulp industries, the overall water consumption has been estimated to be approximately $376 \mathrm{~m}^{3}$ per ton of the product [6].

When it comes to the production of pulp and paper, US mills are a world leader. 9 million tonnes of pulp are produced by these mills ever year. They account for the production of 26 billion newspapers, magazines and books. Mills in the US account for $16 \%$ of the world's total pulp mills. They also make up for $35 \%$ of pulp produced in the world. Hence they also contribute significantly to the pollutants released in environment. Almost 245,000 metric tonnes of air pollutants (that are toxic) are released every year by these mills. There are 19 mills linked with dioxin based fish advisories. The paper mills and pulp industry in America are significant employers. They employ more than 
200,000 people in 42 states. They comprise nation's largest industries and possess almost 565 manufacturing facilities [7].

The basic five key factors that determine the environmental impact of development of industry includes sectoral change, growth, technological development, scale of operations and locations. These key factors are effective when it comes to comparing the environmental effects of industrial sectors of Pakistan and also other Asian countries [2].

About 70 percent of the paper mills in Pakistan are located in the province of Punjab. Generally, Pulp and paper are manufactured from raw materials containing cellulose fibers such as wood, recycled paper, and agricultural residues. Furthermore, in developing countries, about $60 \%$ of cellulose fibers originate from non-wood raw materials such as bagasse (sugar cane fibers), cereal straw, bamboo, reeds, esparto grass, jute, flax, and sisal [3]. Presently, in Pakistan there are about 100 units in the organized and unorganized sectors. Collectively, these units have a staggering set up capacity of 650 thousand tons per annum. The units in organized sectors have a capacity of 20 to 300 tons per day. These organized sectors have 575 thousand tons production capacity from 26 paper manufacturing units. The units produce Writing and Printing Paper, Wrapping and Packing Paper, White duplex coated, Un-coated board, Chip Board and other boards [1].

\subsection{Study Area}

The Paper and Paperboard Mill is located 62-Km, Lahore-Multan Highway N5, District Kasur. It covers an area of more than 16 acres with $50 \%$ of the area being used by the paper mill. The wastewater of the mill is released in the drain after treatment. Agricultural lands were observed in the vicinity of the industry, but very few human settlements were seen due to poor development. The flora of that area was consist of sugar canes, keekar and safaida trees etc. Moreover that area had a vast cultivation of wheat croplands. Livestock included donkeys, horses, street dogs, buffaloes and cows. The industry has it's own Safety and Quality policy. The mill under study established in 1980's, is a Flagship Company of a Leading Group of Companies. The Company serves many of the prestigious clientele and maintains Strategic Business Relationships with leading Packaging and Converting units as well as end users, which include national and multinational companies. The Company is also in export business and its Packaging Boards are successfully competing in the international market.

The plant comprises of:

- Seven Paper Machines (PMs),

- $\quad$ Complete Corrugated Cartons Manufacturing Plant

- Integrated Pulp Mills (Major Inputs Wheat Straw)

- In house Engineering Workshop

- Captive Power Generation Plant

- Chemical House etc.

\section{Methodology}

The methodology that was adopted to carry out the environmental monitoring of Paper and Board Mill is illustrated in the following figure:

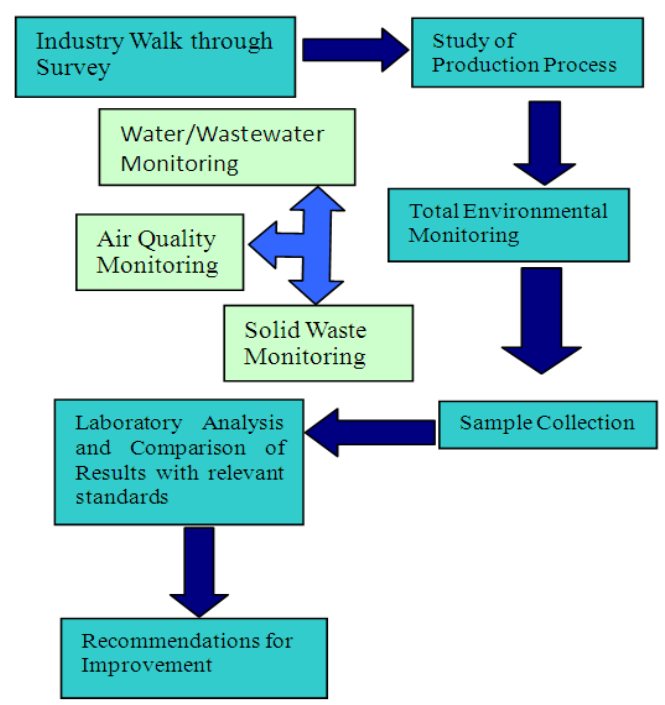

Figure 1. Methodology Outline for Environmental Monitoring of Paper and Board Mill

\subsection{Plant Walk through Survey}

The whole plant was surveyed and it's production processes were studied. The operating procedures, plant conditions, physical setting, resource consumption and utilities were kept in mind and detailed checklists were filled. The inputs and outputs were analyzed by comparing to the recipe provided by the board mill during the secondary data collection.

For each of the production process, material balance was carried out. Materials included raw material, chemicals, bleaching agents etc. The accounting of raw material helped in identifying that how much quantity of waste is expected in the effluent stream and proposed treatment. Energy balance for steam component was also carried out. Moreover, the water consumption was accounted through the digital metering system that was installed in the industry to keep a record of daily water usage. The values were carefully noted and input and output water consumption was calculated. The wastewater was directly sent to the water treatment plant so it was not as such recorded and was related to the benchmark in available literature adopted values. The leakages and drainage systems were carefully observed during the walkthrough survey. The signs and worker's health and safety equipment were also observed.

\subsection{Quantitative and Qualitative Measurements of Wastewater}

Because the wastewater discharge was directly drained in the main drain after treatment, therefore the water balance was carried out in detail. The water that was supplied to 
each unit during the pulping process was measured according to batch wise. Water was measured through bucket and stopwatch process. Grab sampling was undertaken for the quality estimation of treated wastewater before its disposal into the drain. The samples were collected in autoclaved bottles and were preserved and transported to the laboratory for analysis. The wastewater was analyzed for several parameters i.e. $\mathrm{BOD}_{5}, \mathrm{COD}$, TSS, TDS, Temperature, Conductivity, $\mathrm{pH}$, Chlorine and Sulfides. These analysis were performed in the laboratory following the Standard Methods for the examination of water and wastewater as given in Table 1.

Table 1. Analytical Parameters and Methods used

\begin{tabular}{|c|c|c|c|}
\hline $\begin{array}{c}\text { Sr. } \\
\#\end{array}$ & Parameters & Test Method & $\begin{array}{l}\text { Equipment/ Procedure } \\
\text { used }\end{array}$ \\
\hline 1 & COD & APHA 5220-D & Closed Reflux Apparatus \\
\hline 2 & $\mathrm{BOD}_{5}$ & APHA 5210-B & Incubation chamber at $20^{\circ} \mathrm{C}$ \\
\hline 3 & TSS & APHA 2540-D & Filtration Paper, Oven \\
\hline 4 & TDS & APHA 2540-C & Oven dried at $103^{\circ}$ \\
\hline 5 & $\mathrm{pH}$ & EPA 9040-B & $\begin{array}{l}\mathrm{pH} \text { electronic measurement } \\
\text { (on site) }\end{array}$ \\
\hline 6 & Temperature & IMR $2800 \mathrm{P}$ & Certified thermometer \\
\hline 7 & Turbidity & APHA 2130-B & Nephlometric method \\
\hline 8 & Sulfide & НACH 3500 & Methylene blue \\
\hline 9 & Chlorine & $\begin{array}{l}\text { APHA 4500- } \\
\text { CL }\end{array}$ & $\begin{array}{l}\text { Argentometric (Silver } \\
\text { Nitrate) Method }\end{array}$ \\
\hline
\end{tabular}

\subsection{Light, Noise and Air Monitoring}

Light and noise was measured in all departments and units of the mill using LX-107 HA Light meter. In order to check noise level Digital noise level meter was used. The selected parameters for emissions monitoring were Oxides of Nitrogen, Oxides of Sulfur, CO2, CO, Smoke H2S, O2 and smoke etc.

\section{Results and Discussion}

Table 2-9 show the results of analysis and monitoring of different parameters.

\subsection{In-house Environmental Conditions}

The layout of Pulp and Paper mills was excellent in its own class, and maintained a compatible flow of materials. Throughout the industry the processes were connected to prevent long distance transportation costs the plant had its pulping store. Overall the structure of Mill can be rated as comparatively good as compare to other similar plants. The building was made up of concrete and the roof-bearing walls were cemented and plastered. Therefore, few areas in the plant required maintenance and plastering of walls such as chemical storage area required particular attention. The structure was supported by iron pillars. Daylight openings were provided throughout the plant. Production hall was spacious for the movement of trolleys and raw material loading and unloading. The flooring of the plant was tuff tiled and leveled for smooth movement of materials without any obstruction. However, at several areas i.e. chemical house, straw preparation and cooking section the floor had some cracks and imbalances which may hinder chemical transportation and movement. The floor of chemical store, curing area had cemented floor which is leveled and even.

Table 2. Environmental Aspects and their impacts in the selected Industry

\begin{tabular}{|c|c|c|c|}
\hline $\begin{array}{l}\mathrm{Sr} \\
. \#\end{array}$ & $\begin{array}{l}\text { Activity/Product/Goods/Se } \\
\text { rvices }\end{array}$ & $\begin{array}{l}\text { Environmenta } \\
\text { I Aspects }\end{array}$ & $\begin{array}{l}\text { Environment } \\
\text { al Impacts }\end{array}$ \\
\hline 1 & $\begin{array}{l}\text { Cooling of } \mathrm{SO}_{2} \text { gas in } \\
\text { cooling tower }\end{array}$ & $\mathrm{SO}_{2}$ Water & $\begin{array}{l}\text { Water } \\
\text { Pollution }\end{array}$ \\
\hline 2 & $\begin{array}{l}\text { Wheat Straw un-loading, } \\
\text { stacking \& shifting }\end{array}$ & $\begin{array}{l}\text { Fire hazard } \\
\text { (smoking, } \\
\text { welding) }\end{array}$ & $\begin{array}{l}\text { Degradation of } \\
\text { air quality. } \\
\text { Injuries }\end{array}$ \\
\hline 3 & Digester operation & $\begin{array}{l}\text { Lignin leakage, } \\
\text { if gland } \\
\text { packing worn }\end{array}$ & $\begin{array}{l}\text { Water } \\
\text { contamination }\end{array}$ \\
\hline 4 & $\begin{array}{l}\text { Pulp washing and Bleaching } \\
\text { Process }\end{array}$ & $\begin{array}{l}\text { Discharge of } \\
\text { waste water }\end{array}$ & $\begin{array}{l}\text { Water } \\
\text { contamination }\end{array}$ \\
\hline 5 & $\begin{array}{l}\text { Refining, Running of } \\
\text { vacuum pumps, corrugators }\end{array}$ & Noise & $\begin{array}{l}\text { Effect on } \\
\text { hearing power }\end{array}$ \\
\hline 6 & $\begin{array}{l}\text { Thickening of waste paper } \\
\text { pulp }\end{array}$ & $\begin{array}{l}\text { Discharge of } \\
\text { waste water }\end{array}$ & $\begin{array}{l}\text { Water } \\
\text { contamination }\end{array}$ \\
\hline 7 & Pulp screening \& cleaning & $\begin{array}{l}\text { Discharge of } \\
\text { waste water }\end{array}$ & $\begin{array}{l}\text { Water } \\
\text { contamination }\end{array}$ \\
\hline 8 & Sheer Feeding & Mishandling & $\begin{array}{l}\text { Injuries and } \\
\text { accidents }\end{array}$ \\
\hline 9 & Sheet drying & $\begin{array}{l}\text { High } \\
\text { Temperature } \\
\text { and Humidity }\end{array}$ & $\begin{array}{l}\text { Hot and humid } \\
\text { work } \\
\text { environment }\end{array}$ \\
\hline 10 & Coating process & Waste Water & $\begin{array}{l}\text { Water } \\
\text { contamination }\end{array}$ \\
\hline 11 & $\begin{array}{l}\text { Combustion of Natural } \\
\text { Gas/Furnace oil }\end{array}$ & Flue gases & $\begin{array}{l}\text { Degradation of } \\
\text { air quality }\end{array}$ \\
\hline 12 & $\begin{array}{l}\text { Unloading \& shifting of raw } \\
\text { material }\end{array}$ & $\begin{array}{l}\text { Particulate } \\
\text { Matter }\end{array}$ & $\begin{array}{l}\text { Degradation of } \\
\text { air quality. } \\
\text { health hazard }\end{array}$ \\
\hline
\end{tabular}

Table 3. Wastewater Discharge and Waste Load

\begin{tabular}{cccc}
\hline Location & $\begin{array}{c}\text { Wastewater } \\
\text { Volume ( } \mathbf{m}^{\mathbf{3}} / \text { ton of } \\
\text { product) }\end{array}$ & $\begin{array}{c}\text { COD } \\
\text { (kg/ton of } \\
\text { product) }\end{array}$ & $\begin{array}{c}\text { SS (kg/ton } \\
\text { of } \\
\text { product) }\end{array}$ \\
\hline Pulp mill section & 68.9 & 806.5 & 251.4 \\
Paper mill section & 109.6 & 228.6 & 184.4 \\
Factory Combine & 205.6 & 995.2 & 431.8 \\
\hline
\end{tabular}

Table 4. Energy Consumption of the Industry

\begin{tabular}{lc}
\hline \multicolumn{1}{c}{ Item } & Energy Consumption \\
\hline Electricity Energy (kW/ton of product) & 994 \\
Steam (ton/ton of product) & 8.9 \\
\hline
\end{tabular}

The high ceiling ventilation arrangements were made. 
Lighting conditions was overall appropriate only some areas required more illumination to enhance working conditions such as the cooking area, the beating machine area and the storage area.

The main drainage system of Mill was up to the mark and properly covered with one main drain and several internal drains which are combined as one into collection tank before entering wastewater treatment plant and is discharged into the open drain located next to the industry for final disposal. The drain ultimately falls into River Ravi. On regular basis no bar screens were installed to strain out residues which hinder the water flow. The capacity of the main drain that carries the total wastewater of the industry was suitable and its physical condition was also good. Also the plumbing system of the industry was in good condition. The piping network was unclogged and properly maintained.

Table 5. Gaseous Emission Analysis (Sulphur Stack)

\begin{tabular}{clccc}
\hline Sr. \# & Parameters & Units & Results & $\begin{array}{c}\text { Limits as } \\
\text { per NEQS }\end{array}$ \\
\hline 1 & Carbon Monoxide $(\mathrm{CO})$ & $\mathrm{mg} / \mathrm{Nm}^{3}$ & 700 & 800 \\
2 & Sulphur Dioxide $\left(\mathrm{SO}_{2}\right)$ & $\mathrm{mg} / \mathrm{Nm}^{3}$ & 1300 & 1700 \\
3 & $\begin{array}{l}\text { Oxides Of Nitrogen } \\
\left(\mathrm{NO}_{\mathrm{x}}\right)\end{array}$ & $\mathrm{mg} / \mathrm{Nm}^{3}$ & 150 & 600 \\
4 & $\begin{array}{l}\text { Hydrogen Sulphide } \\
\left(\mathrm{H}_{2} \mathrm{~S}\right)\end{array}$ & $\mathrm{mg} / \mathrm{Nm}^{3}$ & 8 & 10 \\
\hline
\end{tabular}

Table 6. Boiler House Emissions

\begin{tabular}{cccc}
\hline Parameters & Unit & Reading 03 & $\begin{array}{c}\text { Limits as per } \\
\text { NEQS }\end{array}$ \\
\hline $\mathrm{CO}_{2}$ & $\%$ & 10.18 & - \\
$\mathrm{O}_{2}$ & $\%$ & 3.92 & - \\
$\mathrm{CO}$ & $\mathrm{mg} / \mathrm{Nm}^{3}$ & 19.00 & 800 \\
$\mathrm{SO}_{2}$ & $\mathrm{mg} / \mathrm{Nm}^{3}$ & 32.00 & 1700 \\
$\mathrm{NO}_{2}$ & $\mathrm{mg} / \mathrm{Nm}^{3}$ & 2.00 & - \\
$\mathrm{NO}$ & $\mathrm{mg} / \mathrm{Nm}^{3}$ & 144.00 & - \\
$\mathrm{NO}$ & $\mathrm{mg} / \mathrm{Nm}^{3}$ & 147.00 & 400 \\
$\mathrm{Smoke}$ & $\mathrm{Ringleman} \mathrm{Scale}$ & 2.00 & 2 \\
\hline
\end{tabular}

Table 7. Wastewater Monitoring (Liquid Effluent) Results

\begin{tabular}{llccc}
\hline \# & Parameters & Unit & $\begin{array}{c}\text { Test } \\
\text { Results }\end{array}$ & $\begin{array}{c}\text { Limits as } \\
\text { per } \\
\text { NEQS }\end{array}$ \\
\hline 1. & Temperature & ${ }^{\circ} \mathrm{C}$ & 29 & $\leq 40$ \\
2. & $\mathrm{pH}$ & - & 5 & $06-09$ \\
3. $\quad$ Biochemical Oxygen & $\mathrm{mg} / 1$ & 726 & 80 \\
4. $\begin{array}{l}\text { Chemand } \\
\text { 5. } \quad \text { Tomal }\end{array}$ & $\mathrm{mg} / 1$ & 1860 & 150 \\
6. & Total Dissolved Solids & $\mathrm{mg} / 1$ & 72 & 200 \\
7. Sulphide & $\mathrm{mg} / 1$ & 2200 & 3500 \\
\hline
\end{tabular}

Table 8. Sound Level Monitoring

\begin{tabular}{|c|c|c|c|c|c|}
\hline \multirow{2}{*}{ Sr. \# } & \multirow{2}{*}{ Department } & \multirow{2}{*}{ Location } & \multicolumn{2}{|c|}{ Sound Level (dBA) } & \multirow{2}{*}{ NEQS (dBA) } \\
\hline & & & Min. & Max. & \\
\hline 1 & \multirow{5}{*}{ Industry Surroundings } & Main Gate \# 1 & 58 & 60 & 85 \\
\hline 2 & & Main Gate \# 2 & 64 & 66 & 85 \\
\hline 3 & & Waste Paper Yard & 62 & 64 & 85 \\
\hline 4 & & Near Effluent Tank & 60 & 62 & 85 \\
\hline 5 & & Power Plant & 76 & 78 & 85 \\
\hline 6 & \multirow{2}{*}{ Straw Plant Unit } & Blower \# 1103 & 84 & 88 & 85 \\
\hline 7 & & Blower \# 1106 & 90 & 92 & 85 \\
\hline 8 & \multirow{2}{*}{ Stock Preparation Plant } & Refining System \# 1 & 90 & 92 & 85 \\
\hline 9 & & Refining System \# 2 & 94 & 96 & 85 \\
\hline 11 & \multirow{3}{*}{$\begin{array}{l}\text { Paper Mill } \\
\text { (PM1) }\end{array}$} & Near Wire Part & 80 & 82 & 85 \\
\hline 12 & & Near Dryer Part & 82 & 84 & 85 \\
\hline 13 & & Vacuum Pumps Area & 98 & 100 & 85 \\
\hline 14 & \multirow{3}{*}{$\begin{array}{l}\text { Paper Mill } \\
\text { (PM2 \& 3) }\end{array}$} & Near Wire Part & 86 & 88 & 85 \\
\hline 15 & & Near Dryer Part & 84 & 88 & 85 \\
\hline 16 & & Vacuum Pumps Area & 96 & 98 & 85 \\
\hline 17 & \multirow{3}{*}{$\begin{array}{l}\text { Paper Mill } \\
\text { (PM5) }\end{array}$} & Near Wire Part & 76 & 78 & 85 \\
\hline 18 & & Near Dryer Part & 76 & 78 & 85 \\
\hline 19 & & Vacuum Pumps Area & 98 & 100 & 85 \\
\hline 20 & Paper Mill & Near Wire Part & 86 & 88 & 85 \\
\hline
\end{tabular}




\begin{tabular}{|c|c|c|c|c|c|}
\hline \multirow{2}{*}{ Sr. \# } & \multirow{2}{*}{ Department } & \multirow{2}{*}{ Location } & \multicolumn{2}{|c|}{ Sound Level (dBA) } & \multirow{2}{*}{ NEQS (dBA) } \\
\hline & & & Min. & Max. & \\
\hline 21 & (PM 7) & Near Dryer Part & 88 & 90 & 85 \\
\hline 22 & & Vacuum Pumps Area & 106 & 108 & 85 \\
\hline 23 & Finishing House & SM 10 Local Sheeter & 102 & 104 & 85 \\
\hline 24 & Utilities & Near Boiler \# 1\& 2 & 102 & 104 & 85 \\
\hline 25 & Stock Preparation Plant PM 7 & Working Area & 76 & 78 & 85 \\
\hline 26 & \multirow{6}{*}{ Board Machine (PM7) } & Wire Part Section & 76 & 77 & 85 \\
\hline 27 & & Press Part & 76 & 78 & 85 \\
\hline 28 & & Dryer Section & 75 & 78 & 85 \\
\hline 29 & & Coating Section & 86 & 88 & 85 \\
\hline 30 & & Re-winder Panel & 82 & 84 & 85 \\
\hline 31 & & Vacuum Pumps Area & 102 & 104 & 85 \\
\hline
\end{tabular}

Table 9. Lighting conditions at each department of the industry

\begin{tabular}{llcc}
\hline Sr. \# & Industry Area & $\begin{array}{c}\text { Illumination in } \\
\text { LUX (lx) }\end{array}$ & $\begin{array}{c}\text { NEQs } \\
(\mathbf{I x )}\end{array}$ \\
\hline 1 & Cooking Area (Digesters) & 82 & 110 \\
2 & Beating Machine & 85 & 110 \\
3 & Machine House (ground floor) & 111 & 110 \\
4 & Vacuum Pump Area & 81 & 110 \\
5 & Office Area & 188 & 110 \\
6 & Finishing House & 90 & 110 \\
7 & Storage Area & 88 & 110 \\
8 & Stock Preparation Plant & 100 & 110 \\
9 & Paper Machine 1 & 115 & 110 \\
10 & Paper Machine 2 & 125 & 110 \\
11 & Paper Machine 3 & 135 & 110 \\
12 & Paper Machine 5 & 114 & 110 \\
13 & Paper Machine 7 & 150 & 110 \\
\hline
\end{tabular}

The chemical handling system at Mill was highly efficient which not only saved excess chemical consumption but also prevented chemical spills and other related hazards or accidents. At the industry, precautionary measures had been taken for chemical dozing. Chemicals are properly labeled and the precautions are prominently mentioned. Material Safety Data Sheets (MSDS) were displayed throughout the chemical handling operations. Only authorized personnel PPE were allowed to handle the chemicals. Personal Protective Equipment (PPEs) were used during chemical handling. Workers were conscious of probable health risks related to the use of such chemicals and preventative measures that can be practiced in case of emergency.

Moreover frequent workshops were at inside the mill to educate the workers about the importance of using Personal protective equipment and the long term effect of their nonusage. Frequent drills were conducted for worker's safety in case of emergency or hazard situation. Pictorial as well as written instructions were displayed throughout the plant walls so that the workers could easily understand and complaint. The instructions were in both Urdu (National language) and English.

Table 3 illustrates the waste water discharge and waste load.

\subsection{Wastewater Quantification}

In pulping process, different procedures require different quantity of wastewater and all of these processes are water intensive. In processes like bleaching and pulping the water quality is distinctive because of the process and chemical usage. Different quantities of wastewater are produced during the cycle of producing paper, from pulping to pulp washing and then its screening and washing leading to bleaching and finally to the paper machine. The wastewater accounted that was discharged by the pulp mill section was $68.9 \mathrm{~m}^{3} /$ ton of product whereas the COD produced was $806.5 \mathrm{~kg} /$ ton of product and SS of $251.4 \mathrm{~kg} / \mathrm{ton}$ of product as shown in Table 3. However the paper mill scenario was a little different. The paper mill section produced wastewater volume of $109.6 \mathrm{~m}^{3} /$ ton of product adding to COD which was $228.64 \mathrm{~kg} /$ ton of product. Overall the factory all combined produced $205 \mathrm{~m}^{3} /$ ton of product of wastewater, $995.2 \mathrm{~kg} /$ ton of COD and $431.8 \mathrm{~kg} / \mathrm{ton}$ of $\mathrm{SS}$. The wastewater contained BOD, COD, TSS, TDS, sulfide etc.

\subsection{Wastewater Characterization}

The $\mathrm{pH}$ of the discharged water after treatment was 5 . The NEQs recommended range for $\mathrm{pH}$ of wastewater is between 6-9. Lower $\mathrm{pH}$ leads to scaling and corrosive nature of water ultimately adding up to the acidity of the receiving waters.

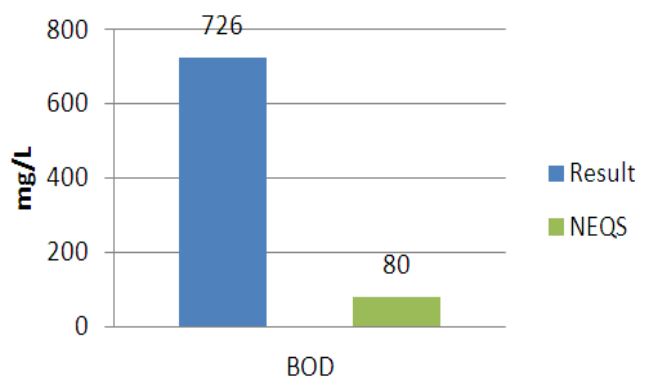

Figure 2. BOD of wastewater after treatment

The BOD of the treated water was way too high than the 
NEQs limit $(80 \mathrm{mg} / \mathrm{l})$ whereas the BOD of wastewater was $726 \mathrm{mg} / 1$ shown in Fig. 2.High BOD leads to stress in the ecosystem and high BOD tends to lower the Dissolved Oxygen of the receiving water.

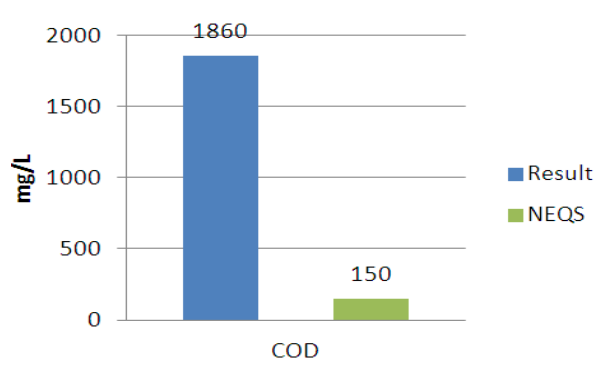

Figure 3. COD of treated wastewater

The treated effluent has a COD of $1860 \mathrm{mg} / \mathrm{l}$ which was more than 10 times higher than the NEQs limit $(150 \mathrm{mg} / \mathrm{l})$. High COD depletes the oxygen and poses threat to the aquatic life in the receiving water body and this released water eventually reaches Ravi River via drain.

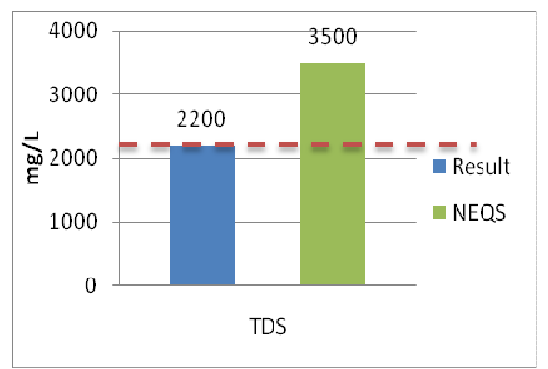

Figure 4. TDS of treated wastewater

Total Suspended Solids are the ones which accumulate on the surface of water and form a thick layer on the top which affects the aquatic life underneath. Moreover it is aesthetically unpleasing. The TSS of the wastewater of the Industry was $72 \mathrm{mg} / \mathrm{l}$ which is very less than the NEQs limits $(200 \mathrm{mg} / \mathrm{l})$. Total Dissolved Solids that were calculated to be $2200 \mathrm{mg} / \mathrm{l}$ however the NEQs limit is 3500 $\mathrm{mg} / \mathrm{l}$. This shows that the wastewater had almost half load less of TDS in the wastewater.

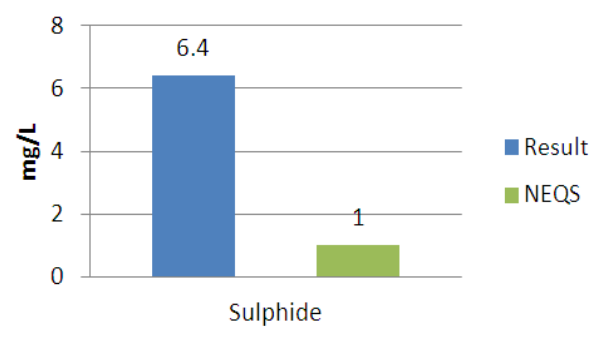

Figure 5. Content of Sulphide present in wastewater

The sulphide content in the wastewater was present due to the chemical usage. The sulphide content found was 6.4 $\mathrm{mg} / \mathrm{l}$ whereas the NEQs only permit the emission of $1 \mathrm{mg} / \mathrm{l}$ (Figure 5).

\subsection{Waste Generation}

The Solid waste that was observed during the walkthrough survey of Industry was in the raw material storage area. The raw material was scattered in the form of bagasse, wheat straw and recycled waste. Moreover there were paper trimmings on the floor of the industry. The industry had treatment sludge, boiler and furnace ash, black liquor etc on the floor of the mill. In the scrapyard there were huge piles of metal scrap and plastic drums of chemicals, which were to be auctioned later to the scrap and waste dealers.

\subsection{Noise, light, Air and Stack Emissions}

Table 8 shows the noise level monitoring results.

The Noise level which is permitted by the NEQs is 85 dB. The Noise level in the Industry was pretty much controlled in most areas except a few which included the Stock Preparation Unit, the PM 7 unit, The finishing house and the utilities as illustrated in Fig 6.

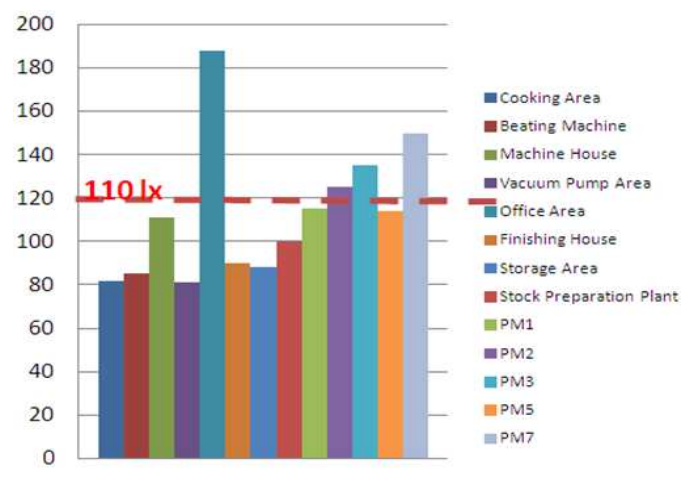

Figure 6. Level of sound in each department of the Industry

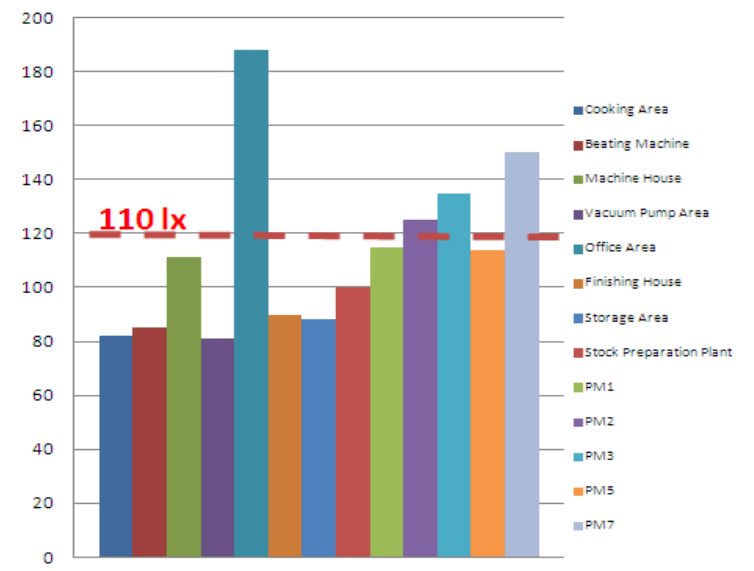

Figure 7. Illumination level in different departments of Paper and board mill

In the mill the lighting conditions were not up to the required standards in most of the areas. Lighting conditions were below the required NEQs i.e. $110 \mathrm{~lx}$ in some areas which show poor ergonomic conditions. According to Occupational Health and Safety Standards, illumination level less than $200 \mathrm{~lx}$ is considered poor illumination and can affect the workers efficiency of work. Thus they require improving the lighting facility. 
Particulate matter was only present in the cooking, depithing unit and the steam boiler area. The PM was calculated to be $8.59 \mathrm{mg} / \mathrm{m}^{3}$ and the minimum recorded was $0.87 \mathrm{mg} / \mathrm{m}^{3}$ which were under the permissible limits by the OSHAS.

The gaseous emissions that were produced by the Stack were Carbon Monoxide (CO), Sulphur Dioxide $\left(\mathrm{SO}_{2}\right)$, Oxides Of Nitrogen $\left(\mathrm{NO}_{\mathrm{x}}\right)$ and Hydrogen Sulphide $\left(\mathrm{H}_{2} \mathrm{~S}\right)$ with emissions of $700,1300,150$ and $8 \mathrm{mg} / \mathrm{Nm}^{3}$ respectively. These all parameters were within the NEQs limits.

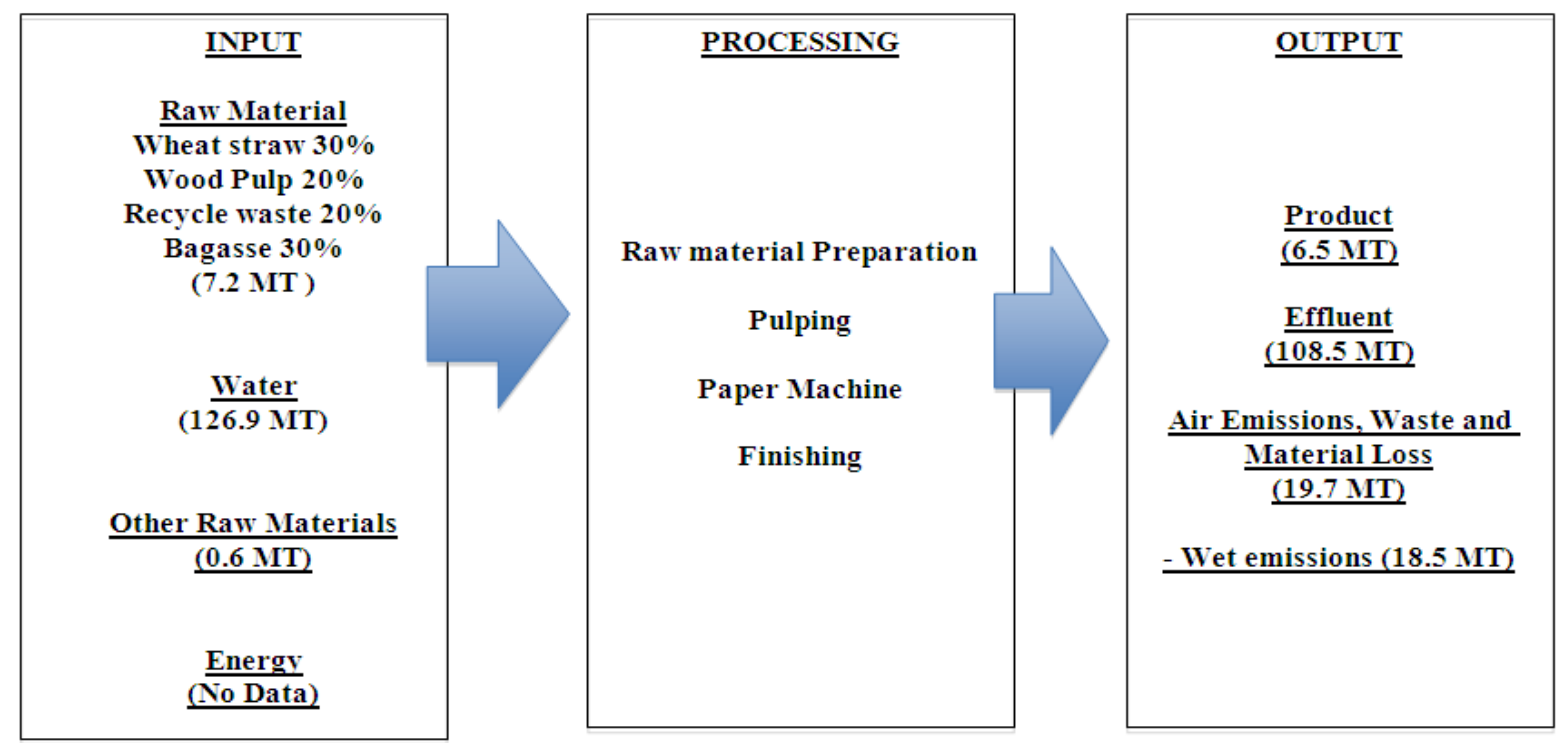

Figure 8. Material Balance of Paper Industry

\subsection{Material Balance}

The Mass Balance provides an indication of material flow through the industry. Whilst it is believed that these figures are a reasonable representation of the industry, it is acknowledged they there may be some inaccuracies due to a lack of data or assumptions made in the analysis. These include the following issues;

- The accurate measurement of some material flows is very difficult, for instance when the weight of the incoming raw materials varies significantly depending on moisture content (normally between $6 \%$ to $10 \%$ );

- Insufficient accurate data is available on waste generated by the industry;

- The loss of material in effluent as dissolved organic and inorganic solids can be $\square$ measured analytically, but no data is available on this;

- Extrapolation of the data from the sample to the whole industry inherently introduces a margin of error.

\section{Conclusion and Recommendations}

To conclude, the study recorded various emissions from the industry including the quantitative and qualitative analysis of waste emissions, physical conditions of the mill, occupational health and safety measures etc. For consumption, Mill produces $205.6 \mathrm{~m}^{3} /$ ton of product compared to the average $230 \mathrm{~m}^{3} /$ ton of product in other large-scale paper mills. Sulphide content that was present due to the use of chemicals turned out to be $6.4 \mathrm{mg} / 1$, which was exceeding the NEQs. BOD and COD emissions in the effluent were also observed to be exceeding the limits. Using a more efficient treatment system can treat them. However other conditions such as, Noise levels, Illumination, ventilation, solid waste management, and electrical systems were all under control and under the NEQs limits. A few problems were identified and measures to mitigate them were recommended.Since, a large portion of fiber and paper wastes are recovered and recycled, solid wastes are of little concern compared with effluent and air emissions for the industry.

It is recommended that:

- The digesters and the steam pipelines should be properly insulated for heat recovery.

- Old water taps should be replaced in order to stop water leakages.

- The rolls should be cleaned in paper machines so that paper does not break.

- The fine piths and dust should be screened in depithed bagasse, which would increase the power consumption and reduce the cooking chemicals and steam.

- Reduced beating time would reduce the electricity consumption

- Usage of soft water as boiler feed would increase the boiler efficiency and reduce scaling.

- Energy audit of the industry must be carried out. 


\section{Conflict of Interest}

The authors declare that there is no conflict of interest.

\section{References}

[1] PCSIR, Problems and Solutions, Pakistan Council of Scientific and Industrial Research, Karachi, 2004.

[2] S.S Ahmad and M.Sohaib, "Report on Paper and Board Industry of Pakistan, SPA, University of Management Technologies," 2010.

[3] ECC (Environment and Conservation Council), Toward Sustainability-Achieving Cleaner Production in Australia, Australia and New Zealand, $16^{\text {th }}$ Meeting, Hobart,
Tasmania,1998.

[4] CIPEC, "Benchmarking energy use in Canadian pulp and paper mills. Eco-energy, an eco-action initiative,Natural resources," Canada, 2008.

[5] TV Anh, "Cleaner Production Audit of Pulp and Paper Industry: A Case Study in Vietnam," Asian Institute of Technology, Bangkok, Thailand, 1996.

[6] NPC (National Productivity Council), "Development of guidelines for water conservation in pulp and paper sector," New Delhi, 2006.

[7] World Bank, Pulp and Paper Mills, Pollution Prevention and Abatement Handbook, World Bank Group, 1998. 